\title{
Мелкомасштабное природно- хозяйственное районирование побережья Тихоокеанской России по природным условиям освоения
}

\author{
КАРАКИН В.П. \\ Федеральное государственное бюджетное учреждение науки \\ Тихоокеанский институт географии ДВО РАН, Владивосток \\ karakin@tigdvo.ru
}

\begin{abstract}
Аннотация. Социально-экономическое развитие российского Дальнего Востока зафиксировано как национальный приоритет РФ на XXI в. Для эффективной реализации заявленных стратегических целей развития необходимо их адаптировать к территориальной масштабности региона, географической и экономической неоднородности пространства, что требует проведения различного вида районирований региона в целом и его субрегионов. При разнообразных подходах к разделению востока Азиатской России на субрегионы практически всеми исследователями в качестве самостоятельного выделяется побережье Тихоокеанской России (береговая зона и территории прилегающих административных районов). Географические особенности данной части российского Дальнего Востока требуют его рассмотрения как отдельного субрегиона с определением сценариев развития. В качестве начального шага в этом процессе разработано мелкомасштабное природно-хозяйственное районирование побережья Тихоокеанской России по природным условиям хозяйственного освоения. Районирование проведено на основе анализа информации о пространственной дифференциации природно-ресурсных факторов, значимых для природопользования и жизнедеятельности в пределах субрегиона: агроклиматических ресурсов, комфортности климата для проживания, ледовых условий и др. Как и при проведении большинства природных районирований, которые в качестве основного фактора дифференциации природных условий рассматривают изменение теплообеспеченности и зональных типов растительности, использована схема разделения пространства побережья Тихоокеанской России на три пояса: арктический, субарктический и умеренный. Окончательно границы поясов и подзон скорректированы с учетом реакции на природные условия территории хозяйственных субъектов. Также выделены два сектора: материковый и островной, важнейшее различие которых - значимость проявления опасных природных явлений. Обосновано, что лучшими условиями хозяйственного освоения, умеренно благоприятными и относительно комфортными для жизнедеятельности и природопользования (товарное сельское хозяйство и др.), в пределах побережья Тихоокеанской России обладает умеренный южнотаежный и лесостепной пояс. Результаты районирования следует учитывать при определении перспектив хозяйственного освоения береговой зоны.
\end{abstract}

Ключевые слова: побережье Тихоокеанской России, береговая зона, природные условия.

\section{Small-scale natural-economic zoning of the coast of Pacific Russia according to the natural conditions of economic development}

\author{
KARAKIN V.P. \\ Pacific Geographical Institute FEB RAS, Vladivostok \\ karakin@tigdvo.ru
}

Abstract. The socio-economic development of the Russian Far East (RFE) is set as one of the national priorities of the Russian Federation for the 21st century. The effective implementation of the stated strategic development goals 
demands adapting to the territorial scale of the region, its geographical and economic heterogeneity by means of various zoning of the region as a whole and its subregions. As an initial step in this process, a small-scale natural-economic zoning of the Coastal Zone of Pacific Russia (CZ PR) was done. This zoning was based on an analysis of information about the spatial differentiation of natural resource factors that are significant for natural resources management and livelihoods within the subregion, namely agro-climatic resources, climate comfort for living, ice conditions, etc. Following the prevailing geographical tradition and most natural zoning approaches, which consider variations in heat supply and zonal types of vegetation as the main factor of differentiation of natural conditions, the author divided the space of the CZ PR into three belts - Arctic, Subarctic and Moderate. Several subzones within each belt are also distinguished according to the changes in heat supply and changes in the type of botanical and geographical subzones. Finally, the borders of the zones and subzones are defined by reaction to the natural conditions of the subjects of regionalization. Two sectors are also distinguished, the Mainland and Island ones. The most important difference between them is in manifestation of dangerous natural phenomena for life and natural resources management. It is substantiated that the moderate Southtaiga and forest-steppe belt within the CZ PR has the best conditions for economic development (moderately favourable and relatively uncomfortable conditions for life and natural resources management, commodity agriculture, etc.). There are no rigid restrictions for port activity due to ice conditions in winter in this belt. The zoning results provide information for selecting the most acceptable strategic development models from the resource and economic point of view for apportioned territories of the CZ PR (belts, subzones) e.g. frontal, focal and pointed ones.

Keywords: Pacific Russia, coastal zone, natural conditions.

\section{Введение}

Территория востока Азиатской России руководством РФ рассматривается как единое пространство. Но внутри этого пространства к востоку от Байкала между его частями существуют различия, и весьма значительные: и по природным условиям, и по экономическому, демографическому, ресурсному потенциалам. Следовательно, и подходы к их развитию должны быть различными. Поэтому разделение данного пространства на крупные географические объекты с собственной природно-хозяйственной спецификой это одно из направлений решения поставленных государством задач регионального развития. При разнообразных подходах к разделению востока Азиатской России на субрегионы практически всеми исследователями в качестве самостоятельного выделяется побережье Тихоокеанской России (ТР), которое рассматривается как береговая зона (БЗ), включающая территории выходящих к морскому побережью административных районов $[1,2]$. Географические особенности побережья ТР, включая БЗ и прилегающие административные районы, требуют его рассмотрения как отдельного субрегиона с определением набора сценариев его будущего развития. В качестве начального шага в этом процессе нами проведено мелкомасштабное природно-хозяйственное районирование побережья ТР по природным условиям хозяйственного освоения. Результаты данного районирования дают информацию по территориальным блокам БЗ ТР в части выбора наиболее приоритетных для хозяйственного освоения территорий.

\section{Материалы и методы}

Природные районирования (физико-географическое, геоботаническое и др.) являются объектными, в их основе лежит исследование территориальной структуры природного объекта, выделение в его рамках соподчиненных единиц, которые обладают внутренним единством и индивидуальными чертами природы. Общенаучные природные районирования выявляют и отражают особенности региональных сочетаний геокомплексов, но в таком виде не раскрывают в должной мере региональные различия в условиях жизни и ведении хозяйства, что требует проведения специализированных природно-хозяйственных районирований (например, агроэкологического, по условиям жизни населения и др.) [3].

Природно-хозяйственные районирования при разнообразии методических подходов их проведения являются объектно-субъектными, т.е. природный объект (географическое пространство) анализируется с точки зрения его использования хозяйственным субъек- 
том. Разнообразие спектра возможных использований географического пространства определяет множественность природно-хозяйственных районирований.

При проведении природно-хозяйственного районирования существуют следующие основные подходы: а) на базе природных выделов, когда территориальные выделы того или иного природного районирования (2-3 уровня) используются как «кирпичики», в пределах которых дается оценка параметров, значимых с хозяйственной точки зрения (например, возможность того или иного вида деятельности по природным зонам и подзонам), и из которых далее формируются единицы природно-хозяйственного районирования высшего уровня; б) на базе экономико-географических выделов. При этом на первом этапе районирования строится поле пространственного распределения исследуемых параметров (климатических, экономических), задаются интервалы, на их основании пространство делится на выделы, в пределах которых далее дается оценка исследуемого параметра с хозяйственной или природной точки зрения

На побережье ТР анализировались природные условия, наиболее значимые для существующего природопользования (весьма ограниченного набора) и функционирования технических систем, которые существуют и могут развиваться в субрегионе. Учитывалось увеличение зависимости хозяйственного комплекса от природных условий по мере роста их экстремальности, когда ограничения на жизнедеятельность и функционирование технических систем становятся более «жесткими», а некоторые виды жизненноважного природопользования, например товарное земледелие, в принципе невозможными. Большая часть пространства побережья ТР расположена в Арктике и Субарктике, где имеет место максимально высокий уровень зависимости меду природными и хозяйственными условиями. Поэтому при выборе методической основы районирования побережья ТР по природным условиям хозяйственного освоения естественно ориентироваться на «природный» подход к природно-хозяйственному районированию, т.е. «на базе природных выделов», с формированием их иерархии по значимости природных условий для жизнедеятельности и хозяйства.

Дифференциация природных условий береговой зоны ТР в рамках данного районирования рассматривалась на основе информационных источников, среди которых в качестве базовых приняты:

1. Комплексное агроэкологическое районирование Дальнего Востока России, которое первоначально подготовлено в 1975 г. сотрудниками географического факультета МГУ и ТИГ ДВО РАН. Далее схема районирования уточнялась [3-5].

2. Карта оценки природных условий жизни населения и Районирование территории России по степени экстремальности природных условий жизни [6, 7].

3. Справочно-нормативные документы строительной климатологии, например СНиП 2.01.07-85 [8].

4. Нормативные зонирования территории РФ с выделением районов Крайнего Севера и местностей, приравненных к районам Крайнего Севера [9].

\section{Результаты и их обсуждение}

Районирование включает в качестве основных единиц природно-хозяйственные пояса. Следуя сложившейся географической традиции и большинству природных районирований, которые в качестве основного фактора дифференциации природных условий рассматривают изменение теплообеспеченности и зональных типов растительности, предлагается пространство БЗ ТР разделить на три пояса: арктический, субарктический и умеренный. В пределах поясов на основе оценки теплообеспеченности выделены подзоны, которые далее оцениваются с природно-хозяйственной точки зрения. Окончательно границы поясов и подзон определены с учетом реакции на природные условия хозяйственных субъектов. 
1. Умеренный южнотаежный и лесостепной пояс с лучшими в регионе природными условиями хозяйственного освоения. Географическое пространство в границах пояса обладает умеренно благоприятными и относительно комфортными условиями для жизнедеятельности и природопользования, например товарного сельского хозяйства и др. Также в пределах пояса нет «жестких» ограничений для портовой деятельности по ледовой обстановке в зимний период.

Подзоны:

1.1. Южных хвойно-широколиственных лесов (ХШЛ) и лесостепи;

1.2. Средних хвойно-широколиственных лесов;

1.3. Северных хвойно-широколиственных лесов;

1.4. Южной тайги.

2. Субарктический лесотундрово-таежный пояс с природными условиями, ограниченно пригодными для хозяйственного освоения. Географическое пространство в границах пояса характеризуется в целом дискомфортным уровнем условий для жизнедеятельности и природопользования. С учетом большой изменчивости природных условий здесь существует возможность нахождения локальных ареалов с меньшими ограничениями для хозяйственного освоения.

Подзоны:

2.1. Средней тайги;

2.2. Северной тайги;

2.3. Лесотундры.

3. Арктический тундровый пояс с экстремально суровыми природными условиями хозяйственного освоения и жизнедеятельности. Эти условия требуют затратных технологических решений, что оправдывается только стратегической государственной необходимостью (например, обеспечение функционирования Севморпути) или уникальными природными ресурсами. Аборигенное природопользование в пределах данного пояса - это вопрос отдельного рассмотрения.

Методически более строгим было бы разделение пояса на зоны и далее выделение подзон. Но учитывая, что: а) в данной работе природные подзоны используются как «территориальные единицы» с их последующей природно-хозяйственной интерпретацией; б) пространство природных зон (например, таежной) разделено между умеренным и субарктическим поясами; в) введение «зон» как уровня районирования усложнит иерархию его единиц, - в данном районировании предлагаем ограничиться выделением подзон.

Схема районирования БЗ ТР по природным условиям хозяйственного освоения представлена на рис. 1. Предлагается расширить границы субарктического пояса по сравнению с границами данного пояса в рамках известных физико-географических районирований [10-12] и провести южную границу субарктического пояса по природным условиям хозяйственного освоения в БЗ ТР в районе Татарского пролива. Последний находится южнее границ Субарктики с точки зрения классических физико-географических районирований [12].

Предлагаемая нами граница обосновывается суровостью зимних климатических условий для природопользования и жизни населения в южном Приохотье и низовьях Амура и севернее. Это проявляется не только в зимних температурах, но и в их сочетании с ветровой нагрузкой, что отражает индекс Хилла, рассчитанный для данной территории [13].

А.Н. Демьяненко, анализируя пространственно-временное распределение индекса Хилла, отмечает смещение на юг РДВ «территорий, отнесенных к категории очень дискомфортных условий проживания». «Хотя территории, отнесенные к категории очень дискомфортных условий проживания, совпадают с зоной арктических пустынь и побережьем морей Северного Ледовитого океана, в пределах ДФО нередки случаи, когда территории с аналогичными условиями располагаются далеко за пределами арктической зоны. Пример Чумикана, а точнее побережья Удской губы, тому подтверждение» [13, с. 145]. 


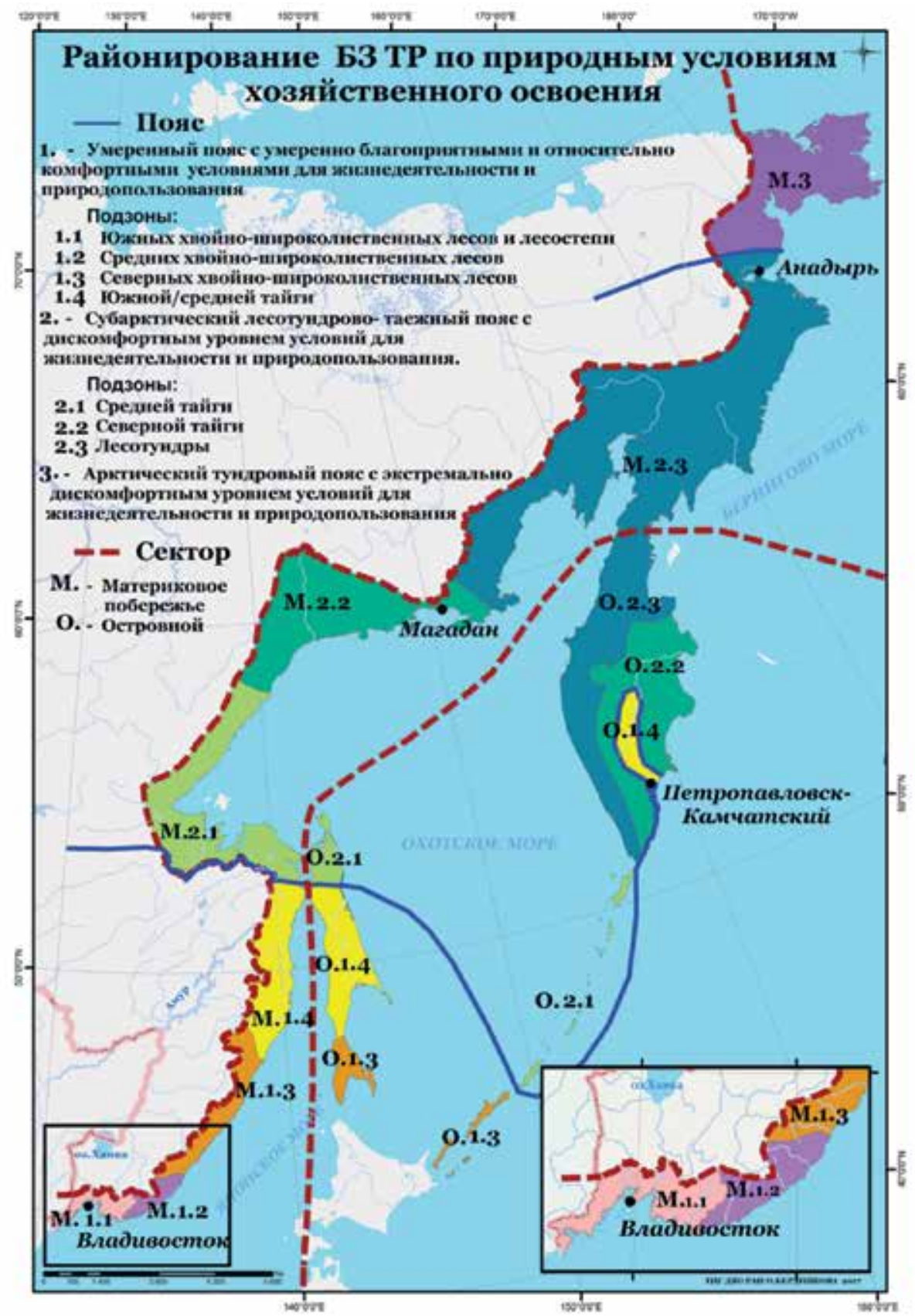

Рис. 1. Схема районирования БЗ ТР по природным условиям хозяйственного освоения

Fig. 1. The scheme of zoning of the coastal zone of Pacific Russia according to the conditions for economic development

Приведенный ниже график (рис. 2) показывает суровость температур в г. Николаевскена-Амуре по сравнению с г. Архангельск, который традиционно относят к Субарктике [12], а рис. 3 характеризует близость климатических условий (безморозный период) в пределах умеренного пояса от Николаевска-на-Амуре до Анадыря [16].

В авторитетных работах по интегральной оценке условий жизнедеятельности для пространства СССР и РФ [6,7], например на «Карте оценки природных условий жиз- 


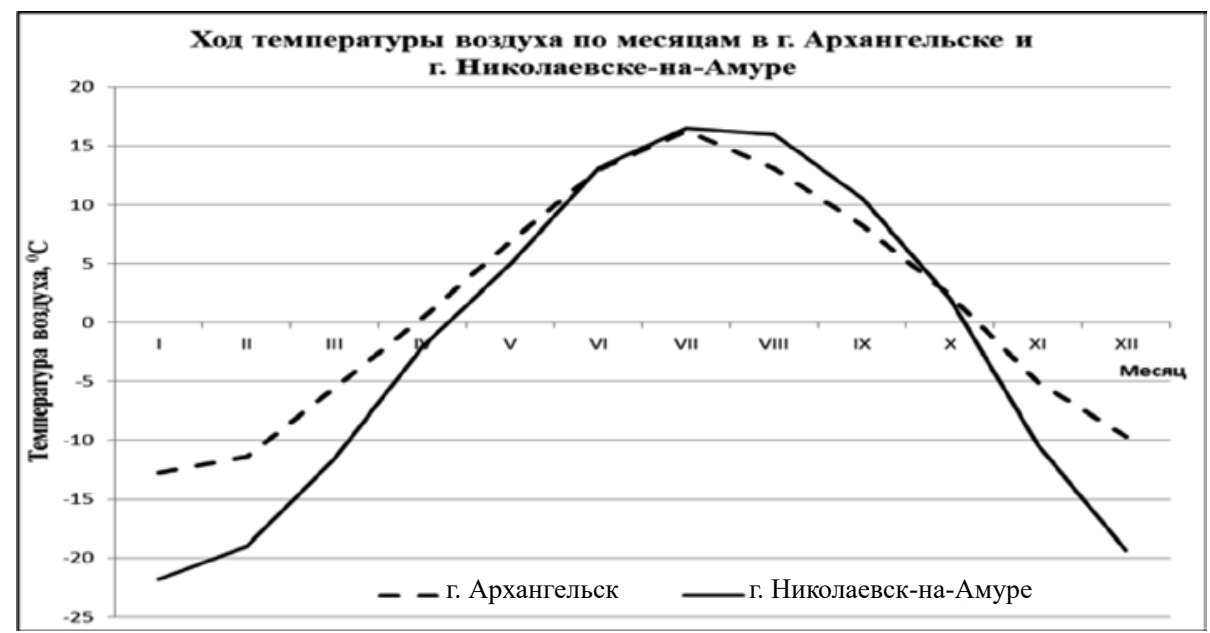

Рис. 2. Температура воздуха в городах Архангельск и Николаевск-на-Амуре. Источник: $[14,15]$

Fig. 2. The air temperature in the cities of Arkhangelsk and Nikolaevsk-na-Amure [14, 15]

ни населения СССР», составленной О.Р. Назаревским в 1970-х годах, береговая зона ТР начиная с границы между Приморским и Хабаровским краями до границы Корякского и Чукотского округов отнесена к территориям с малоблагоприятными условиями жизни населения. Фактически она рассматривается как Субарктика. Предлагаемая нами южная граница субарктического пояса находится южнее физико-географических границ Субарктики и севернее границы, проводимой О.Р. Назаревским по условиям жизни населения [6] практически на 0,5 тыс. км.

Характеристика единиц районирования по основным параметрам, значимым для природных условий хозяйственного освоения, приведена в табл. 1.

Анализируя характеристики, необходимо отметить, что градиенты теплообеспеченности а именно сумм температур более 10 градусов в пределах умеренного и субарктического поясов при их различной меридиональной протяженности близки и составляют $800-1000{ }^{\circ} \mathrm{C}$. В умеренном поясе на протяжении 1,5 тыс. км с юга на север теплообеспеченность меняется от 2600 до $1600{ }^{\circ} \mathrm{C}$. Это зона товарного сельского хозяйства. В субарктическом поясе на протяжении около 3 тыс. км с юга на север теплообеспеченность меняется от 1600 до $600-800{ }^{\circ} \mathrm{C}$. Это зона ограниченного локального сельского хозяйства, ориентированного на местное самообеспечение: выращивание овощей, животноводство. Повышенное внимание, уделяемое агроклиматическим показателям, объясняется тем, что последние, кроме непосредственных условий возможности ведения сельского хозяйства, характеризуют также комплекс условий жизнедеятельности.

При мелкомасштабном разделении БЗ ТР по природным условиям хозяйственного освоения, кроме поясов и подзон, необходимо учитывать секторность в дифференциации рассматриваемых природно-хозяйственных условий (табл. 2). Предлагается выделить два сектора:

- островной - о-в Сахалин, Курильские острова, п-в Камчатка до Парапольского дола, Командорские острова;

- материковый - материковое побережье.

Секторная дифференциация в пределах рассматриваемого географического пространства проявляется в границах умеренного и субарктического поясов. Основные различия секторов, которые выделены в пределах умеренного и субарктического поясов, проявляются в следующем.

1. В островном секторе в пределах субарктического и умеренного пояса - более мягкие температурные условия для природопользования и жизнедеятельности в зимний период по сравнению с материковым побережьем. Максимально это выражено в пределах субар- 
ктического пояса, но здесь отмечается повышенная ветровая и снежная нагрузка в зимний период.

2. В островном секторе по сравнению с материковым побережьем существует принципиально более высокий риск ЧС (чрезвычайных ситуаций), обусловленных природными факторами (сейсмичность, опасность цунами, снеговая и ветровая нагрузки и др.). Более подробно различия секторов по ряду характеристик отражает табл. 2. Необходимо отметить, что здесь рассматривается не весь набор особо опасных явлений (ОПЯ), который осложняет природопользование и жизнедеятельность в Б3 ТР. Полный каталог ОПЯ, присущих данным территориям, значительно шире, только для о-ва Сахалин их несколько десятков [17].

С точки зрения хозяйственного освоения различия физико-географических условий островного и материкового секторов БЗ ТР являются принципиальными, т.е они требуют для каждого сектора собственной стратегии развития природопользования и адаптации населения и технических систем (в первую очередь, инфраструктурных) к комплексу природных условий. Имеющийся опыт регионааналога, Японии, подтверждает возможность выработки такой эффективной стратегии к существующему в островном секторе набору ОПЯ и специфике природных условий. При положительной оценке японского

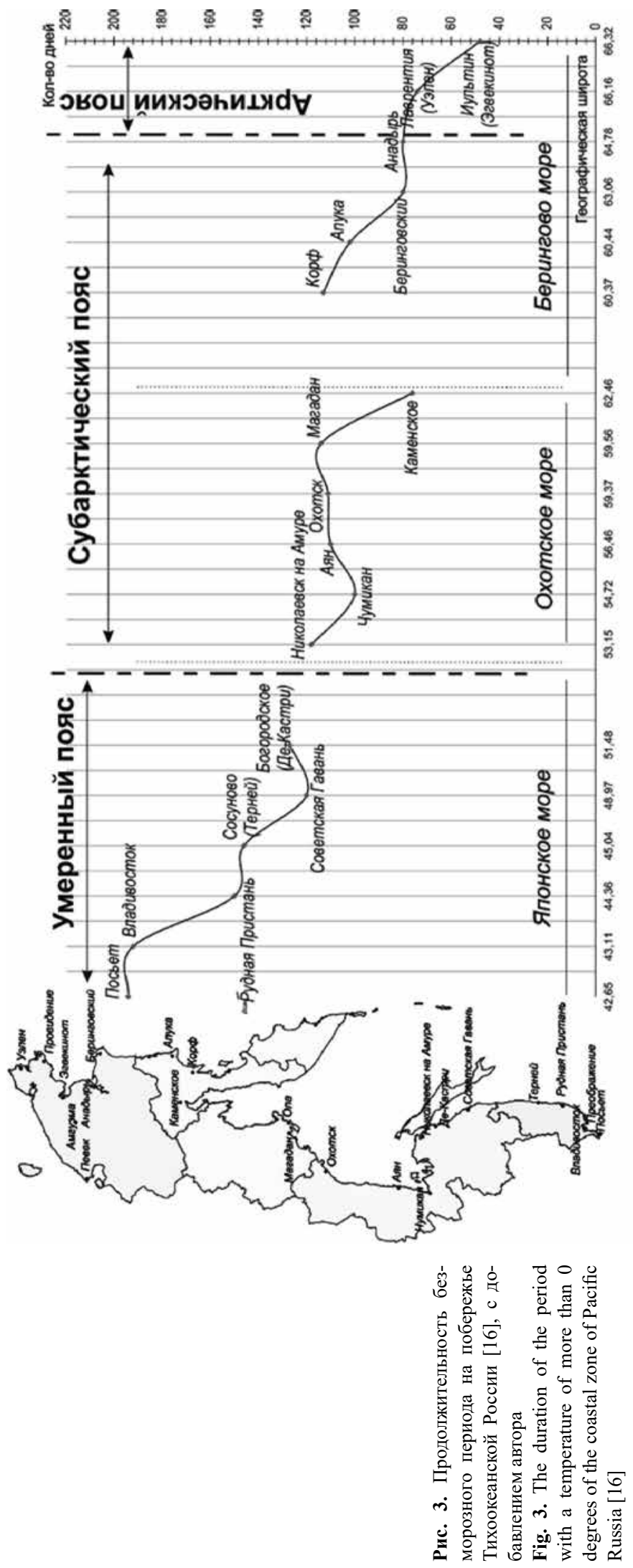


تٓ

\begin{tabular}{|c|c|c|c|c|c|c|c|c|c|c|c|c|c|}
\hline है & 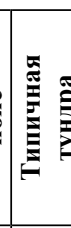 & $\begin{array}{l}8 \\
0 \\
0 \\
8 \\
q\end{array}$ & 8 & 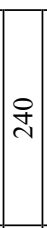 & & & ్ָరి & 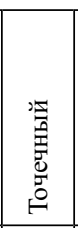 & 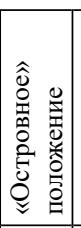 & $\frac{0}{i}$ & 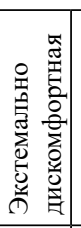 & $\begin{array}{l}\sum_{0} \\
\vdots \\
\vdots \\
0 \\
\vdots \\
\vdots \\
\vdots \\
\vdots\end{array}$ & 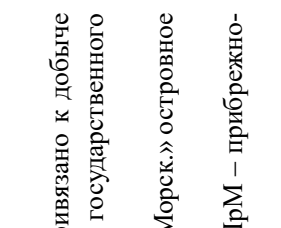 \\
\hline $\overrightarrow{\underline{\underline{H}}}$ & 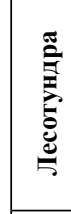 & $\begin{array}{l}8 \\
8 \\
\vdots \\
8 \\
i n\end{array}$ & $\begin{array}{l}2 \\
1 \\
b\end{array}$ & & & $\frac{m}{+}$ & & 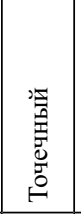 & 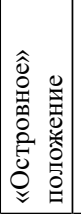 & 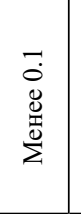 & 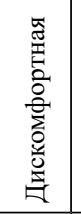 & $\begin{array}{l}\dot{Q} \\
\dot{4} \\
\dot{\Sigma}\end{array}$ & 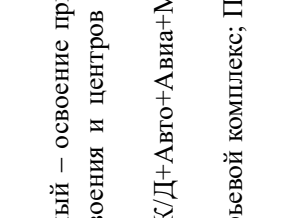 \\
\hline 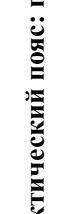 & لَّ & 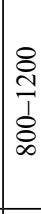 & $\begin{array}{l}8 \\
\frac{1}{2} \\
2\end{array}$ & $\stackrel{\vec{\imath}}{\mathrm{i}}$ & & $\stackrel{\circ}{+}$ & 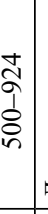 & 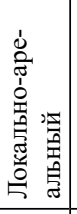 & 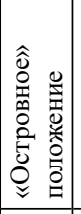 & 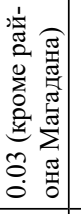 & 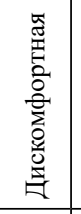 & 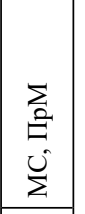 & 章 \\
\hline 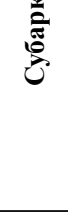 & 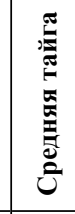 & $\begin{array}{l}8 \\
8 \\
0 \\
8 \\
0 \\
\text { d }\end{array}$ & $\frac{8}{\frac{8}{1}}$ & 0 & & $\cong$ & : & 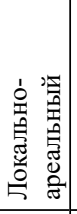 & 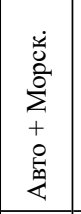 & ? & 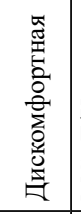 & 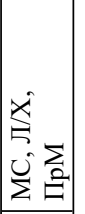 & 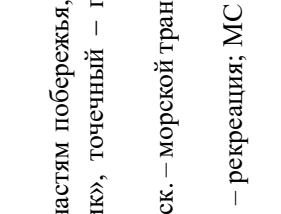 \\
\hline \multirow{4}{*}{ 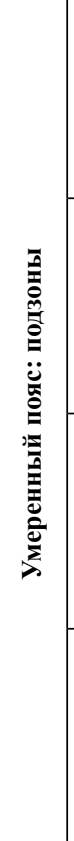 } & 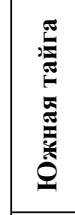 & $\begin{array}{l}8 \\
0 \\
1 \\
8 \\
0 \\
-0\end{array}$ & $\begin{array}{l}q \\
\text { d } \\
\text { ปิ }\end{array}$ & $\mid \begin{array}{c}\sigma \\
-6\end{array}$ & & $\simeq$ & $\stackrel{R}{R}$ & 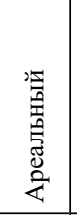 & 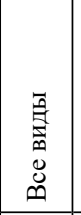 & $\stackrel{9}{=}$ & 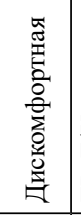 & 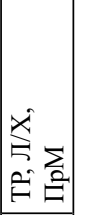 & 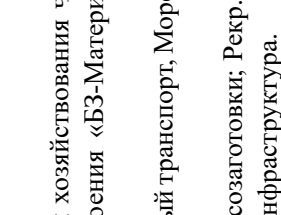 \\
\hline & U. & $\begin{array}{c}8 \\
o \\
i \\
o \\
\infty \\
\infty\end{array}$ & $\begin{array}{l}\hat{\jmath} \\
\infty \\
ٍ \\
=\end{array}$ & $\left|\begin{array}{c}8 \\
-1 \\
1 \\
-2\end{array}\right|$ & & $=$ & 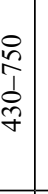 & 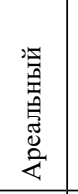 & 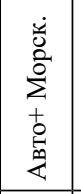 & $\stackrel{\infty}{\rightarrow}$ & 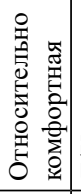 & 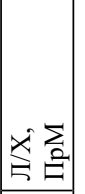 & 胥 \\
\hline & 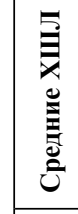 & 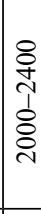 & 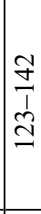 & $\cong$ & & $\approx$ & $\begin{array}{l}\tilde{N} \\
\infty \\
\vdots \\
n \\
n\end{array}$ & 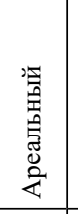 & 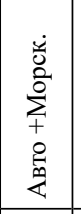 & $\stackrel{m}{m}$ & 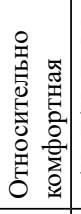 & 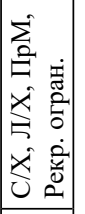 & 3 \\
\hline & 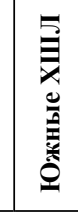 & 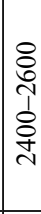 & $\begin{array}{l}n \\
\frac{n}{1} \\
\frac{1}{n}\end{array}$ & & & $\infty$ & 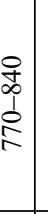 & 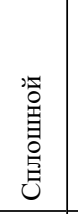 & 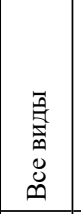 & 5 & 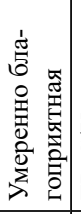 & 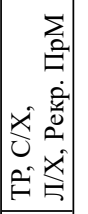 & 递 \\
\hline \multicolumn{2}{|r|}{ 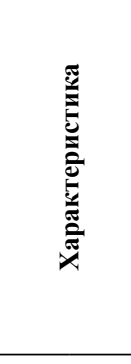 } & $\begin{array}{l}0 \\
0 \\
0 \\
0 \\
0 \\
0 \\
0\end{array}$ & 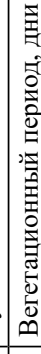 & 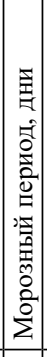 & 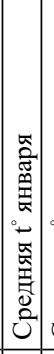 & 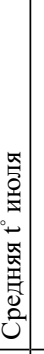 & 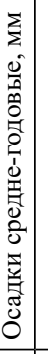 & 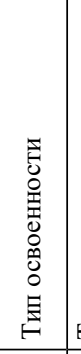 & 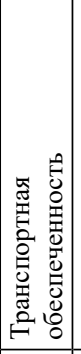 & 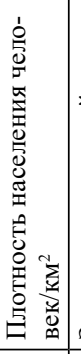 & 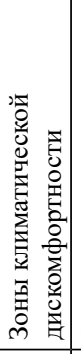 & 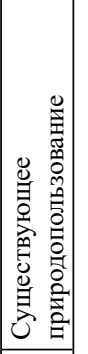 & 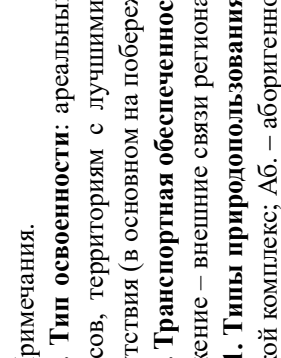 \\
\hline & & & & & ${ }^{\nabla}$ & $n$ & 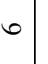 & $r$ & $\infty$ & $a$ & $\stackrel{\ominus}{-}$ & - & \\
\hline
\end{tabular}


Характеристика единиц районирования береговой зоны ТР по опасным природным явлениям (ОПЯ)

Table 2. Zoning of the coastal zone of Pacific Russia according to the natural conditions for economic development: comparison of 'In-land' and 'Island' sectors

\begin{tabular}{|c|c|c|c|c|c|}
\hline \multirow[b]{2}{*}{$\begin{array}{c}\text { № } \\
\text { ПI/I }\end{array}$} & \multirow[b]{2}{*}{ Характеристика ОПЯ } & \multicolumn{2}{|c|}{ Умеренный пояс: сектора } & \multicolumn{2}{|c|}{ Субарктический пояс: сектора } \\
\hline & & $\begin{array}{c}\text { Материковое } \\
\text { побережье } \\
\text { (Ольга, Сов. } \\
\text { Гавань) } \\
\end{array}$ & $\begin{array}{c}\text { Островное } \\
\text { побережье (Юж- } \\
\text { но-Сахалинск - } \\
\text { Южно-Курильск) } \\
\end{array}$ & \begin{tabular}{|c|} 
Материковое \\
побережье (Нико- \\
лаевск, Аян, \\
Охотск) \\
\end{tabular} & $\begin{array}{c}\text { Островное } \\
\text { побережье } \\
\text { (Оха-мыс } \\
\text { Лопатка) } \\
\end{array}$ \\
\hline 1 & $\begin{array}{l}\text { Опасность землетрясений, } \\
\text { баллы по шкале MSK-64 }\end{array}$ & $6-7$ & 9 & $\begin{array}{c}\text { 6-8 } \\
\text { Район Магадана } \\
-9\end{array}$ & 8-9 и более \\
\hline 2 & $\begin{array}{l}\text { Опасность снеговых на- } \\
\text { грузок в КПа * }\end{array}$ & $\begin{array}{c}\text { От менее } 1 \text { до } \\
3.5\end{array}$ & От 2 до 5 & От 1 до 3.5 & $\begin{array}{c}\text { От } 3.5 \text { до } 10 \text { и } \\
\text { более }\end{array}$ \\
\hline 3 & $\begin{array}{l}\text { Вероятность цунами для } \\
\text { интервала повторяемости } \\
1000 \text { лет }\end{array}$ & $0-4$ & 2-6 и более & $0-2$ & Более 6 \\
\hline 4 & $\begin{array}{l}\text { Средняя месячная темпе- } \\
\text { ратура воздуха в январе, }{ }^{\circ} \mathrm{C}\end{array}$ & от -20 до -15 & от -15 до -10 & -20 & От -15 до -10 \\
\hline 5 & $\begin{array}{l}\text { Средняя месячная темпе- } \\
\text { ратура воздуха в июле, }{ }^{\circ} \mathrm{C}\end{array}$ & $17-15$ & $10-15$ & $10-15$ & 10 \\
\hline 6 & Вечная мерзлота & $\begin{array}{c}\text { Практически } \\
\text { отсутствует }\end{array}$ & $\begin{array}{c}\text { Практически } \\
\text { отсутствует }\end{array}$ & $\begin{array}{c}\text { Локальная вечная } \\
\text { мерзлота }\end{array}$ & $\begin{array}{c}\text { Практически } \\
\text { отсутствует }\end{array}$ \\
\hline 7 & Морозный период, дни** & $\begin{array}{c}137-162 \\
\text { Пластун - Сов. } \\
\text { Гавань } \\
\end{array}$ & $\begin{array}{c}\text { 153-119 (Южно- } \\
\text { Сахалинск - Юж- } \\
\text { но-Курильск) } \\
\end{array}$ & $187-210$ & $\begin{array}{c}\text { 190-169 Оха - } \\
\text { мыс Лопатка }\end{array}$ \\
\hline
\end{tabular}

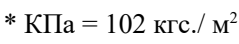

** Средняя дневная температура $=0{ }^{\circ} \mathrm{C}$ или ниже.

Источники: $[8,19,20]$.

опыта необходимо учитывать, что он реализуется в более южных (комфортных) для проживания условиях; сформировался в течение мновековой адаптации населения и хозяйства к специфике природных условий; требует высочайшего уровня технологического и финансового обеспечения.

Одним из стратегических вариантов уменьшения рисков ЧС от ОПЯ в пределах островного сектора при необходимости размещения технологически сложных объектов является максимальное использование возможностей их размещения на материковом побережье. Это наиболее реалистично в пределах умеренного пояса, где островной и материковый сектора территориально близки. Примером использования данной схемы территориального размещения высокотехнологического объекта является «посадка» в бухте Де-Кастри нефтеналивного терминала для отправки сахалинской нефти [18].

\section{Заключение и выводы}

На мелкомасштабном уровне по природным условиям хозяйственного освоения побережье ТР (БЗ и территории прилегающих административных районов) делится на три пояса (умеренный, субарктический и арктический) и два сектора (материковый и островной). На данном уровне членения пространства региона можно дать следующую стратегическую оценку природным условиям хозяйственного освоения.

1. Лучшими в регионе природными условиями хозяйственного освоения обладает умеренный южнотаежный и лесостепной пояс. Географическое пространство в границах пояса обладает умеренно благоприятными и относительно комфортными условиями для жизнедеятельности и природопользования. Также в пределах пояса нет «жестких» ограничений для портовой деятельности по ледовой обстановке в зимний период. 
В программных документах по развитию Дальнего Востока приводится тезис о поляризованной территориальной структуре развития региона, что предполагает освоение севера вахтовым методом и формирование на юге зоны ускоренного фронтального развития. Предлагаемая в данном районировании граница между умеренным и субарктическим поясом может служить объективным рубежом между зоной фронтального освоения в южной части региона и зоной вахтового развития в северной части в пределах побережья ТР.

В дифференциации природных условий хозяйственного освоения в пределах умеренного пояса важнейшими являются различия в частоте проявления и локализации последствий ОПЯ в пределах материкового и островного секторов умеренного пояса. При этом комплекс природно-хозяйственных условий подзон южных хвойно-широколиственных лесов и лесостепи и средних хвойно-широколиственных лесов в настоящее время в должной мере не оценен.

2. Субарктический лесотундрово-таежный пояс обладает ограниченно пригодными природными условиями хозяйственного освоения. Территория в границах пояса характеризуется в целом дискомфортным уровнем условий для жизнедеятельности и природопользования. Учитывая громадность данного пространства и изменчивость природных условий, при ориентировании на очаговое освоение побережья можно использовать возможность нахождения локальных ареалов с менее ограниченными природными условиями хозяйственного освоения. Также перспективно использование возможности формирования опорно-тыловых баз для хозяйственного освоения Субарктики на прилегающих к ней районах умеренного пояса (Де-Кастри, Петропавловск-Камчатский и т.д.).

3. Арктический тундровый пояс - пространство с экстремально суровыми природными условиями хозяйственного освоения и жизнедеятельности. Эти условия требуют затратных технологических решений, что оправдывается только стратегической государственной необходимостью (например, обеспечение функционирования Севморпути) или уникальными по составу или качеству природными ресурсами.

\section{Литература}

1. Геосистемы Дальнего Востока России на рубеже XX-XXI веков: Т. 1 / Ганзей С.С. (отв. ред.). Владивосток, Дальнаука, 2008. 428 с.

2. Геосистемы Дальнего Востока России на рубеже XX-XXI веков: Т. 2: Природные ресурсы и региональное природопользование / Бакланов П.Я., Каракин В.П. (отв. ред.). Владивосток: Дальнаука, 2010. 558 с.

3. Зворыкин К.В. и др. Прогноз состояния сельскохозяйственных земель Дальнего Востока на 2000-й год». Отчет НИР Географического факультета МГУ за 1973 и 1974 гг., выполненных по договору с ДВНЦ АН СССР. М.: МГУ, 1974. 294 с. Фонды ТИГ ДВО РАН.

4. Дейнекина Н.И., Каракин В.П., Степанько А.А. и др. Агроэкологическое районирование юга Дальнего Востока // Природное и сельскохозяйственное районирование СССР. М.: Изд.-во МГУ, 1979. С. 179-185.

5. Степанько А.А., Каракин В.П. Агроэкологическое пространство // Геосистемы Дальнего Востока России на рубеже веков. Т. 2. Владивосток: Дальнаука, 2010. С. 54-64.

6. Назаревский О.Р. Карта оценки природных условий жизни населения СССР // Ресурсы. Среда. Расселение. М.: Наука, 1974. С. 189-199.

7. Золотокрылин А.Н., Канцебовская И.В., Кренке А.Н. Районирование территории России по степени экстремальности природных условий жизни // Изв. АН. Серия геогр. 1992. № 6. С. 16-30.

8. Нагрузки и воздействия. Свод правил. СНиП 2.01.07.85. М.: Минрегионразвития РФ. 2011. [Электронный pecypc]. Режим доступа: https://dokipedia.ru/document/5340694. (дата обращения: 15.03.2016).

9. Лаженцев В.Н. Север России: вопросы пространственного и территориального развития. Сыктывкар: КНЦ УроРАН, 2015. 174 с.

10. Гвоздецкий Н.А. Физико-географическое районирование СССР. М.: МГУ, 1968. 576 с.

11. Исаченко А.Г. Ландшафты СССР. Л.: ЛГУ, 1985. 320 с.

12. Григорьев А.А. Субарктика: Опыт характеристики основных типов физико-географической среды. М.; Л.: Изд-во АН СССР, 1946. 170 с.

13. Демьяненко А.Н., Демьяненко Н.А. Опыт количественной оценки биоклиматических условий для целей регионального стратегирования (на примере Дальнего Востока) // Пространственная экономика. 2012. № 4. C. $138-154$.

14. Научно-прикладной справочник по климату СССР. Серия 3. Многолетние данные. Ч. 1-6. Вып. 1. Л.: Гидрометеоиздат, 1989. 483 с. 
15. Научно-прикладной справочник по климату СССР. Вып. 25. СПб.: Гидрометеоиздат, 1992. 559 с.

16. Сорокин П.С. Температура воздуха как лимитирующий фактор организации хозяйственной деятельности на Тихоокеанском побережье РФ // Геосистемы Северо-Восточной Азии: особенности их пространственновременных структур, районирование территории и акватории. Владивосток: ИП Мироманова, 2019. С. 557-562.

17. Опасный остров. Природные риски Сахалина // Инженерная защита. 2015. № 7. С. 24-28.

18. Нефтеотгрузочный терминал Де-Кастри проекта «Сахалин-1». [Электронный ресурс]. Режим доступа: https://sakhalin.info/news/109770 (дата обращения: 11.12.2015).

19. Атлас природных и техногенных опасностей и рисков ЧС. М.: МЧС России, 2007. 324 с.

20. Карта цунами опасности Дальневосточного побережья РФ для интервала повторяемости 1000 лет. [Электронный ресурс]. Режим доступа: - https://nat-geo.ru/nature/sostavlena-karta-tsunami-opasnosti-v-regionakhrossii/. (дата обращения: 28.09.2018).

\section{References}

1. Geosystems of the Russian Far East at the turn of the XX-XXI centuries: volume 1: ed. Gansey S.S., Dalnauka: Vladivostok, Russia, 2008, 428 p. (In Russian)

2. Geosystems of the Russian Far East at the turn of the XX-XXI centuries: volume 2: Natural resources and regional nature management/ ed. Baklanov P.Ya., Karakin V.P. Dalnauka: Vladivostok, Russia, 2010, 558 p. (In Russian)

3. Zvorykin, K.V. et al. Forecast of the state of agricultural lands in the Far East to 2000. Report of the Research Department of the Geographical Faculty of Moscow State University for 1973 and 1974, performed under an agreement with the Center for Scientific Research of the Academy of Sciences of the USSR, Moscow State University: Moscow, Russia, 1974, 294 p. (In Russian)

4. Deinekina, N.I., Karakin, V.P., Stepanko, A.A. et al. Agroecological zoning of the south of the Far East. Natural and agricultural zoning of the USSR. Publishing House of Moscow State University: Moscow, Russia, 1979, $179-185$. (In Russian)

5. Stepanko, A.A., Karakin, V.P. Agroecological space. Geosystems of the Russian Far East at the turn of the century. Vol. 2, Dalnauka: Vladivostok, Russia, 2010, 54-64. (In Russian)

6. Nazarevsky, O.R. Map of the assessment of the natural living conditions of the population of the USSR. Resources environment resettlement. Nauka: Moscow, Russia, 1974, 189-199. (In Russian)

7. Zolotokrylin, A.N., Kantsebovskaya, I.V., Krenke, A.N. Zoning of the territory of Russia by the degree of extremality of natural living conditions. Izvestia AN Series geografia. 1992. 6, 16-30. (In Russian)

8. Loads and impacts. Set of rules. SNiP 2.01.07.-85. Ministry of Regional Development of the Russian Federation: Moscow, Russia, 2011. (In Russian)

9. Lazhentsev, V.N. North of Russia: issues of spatial and territorial development. Syktyvkar, Russia, 2015, $174 \mathrm{p}$. (In Russian)

10. Gvozdetsky, N.A. Physical-geographical zoning of the USSR. Moscow State University: Moscow, Russia, 1968, 576 p. (In Russian)

11. Isachenko, A.G. Landscapes of the USSR. Leningrad State University: Leningrad, Russia, 1985, 320 p. (In Russian)

12. Grigoriev, A.A. Subarctic: Experience characterizing the main types of physical and geographical environment. M.; L.: Publishing House of the Academy of Sciences of the USSR: Moscow, Russia, 1946, 170 p. (In Russian)

13. Demyanenko, A.N., Demyanenko, N.A. Experience in the quantitative assessment of bioclimatic conditions for the purposes of regional strategic planning (on the example of the Far East). Spatial Economics, 2012, 4, $138-154$. (In Russian)

14. Scientific-applied reference on the climate of the USSR. Series 3 Perennial data. Pt. 1-6. Issue 1. Gidrometeoizdat: Leningrad, 1989, 483 p. (In Russian)

15. Scientific-applied reference on the climate of the USSR. Vol. 25. Gidrometeoizdat: St. Petersburg, Russia, 1992, 559 p. (In Russian)

16. Sorokin, P.S. The air temperature as limiting factor of economical activity organization on Russian pacific coast. Geosystems of North-East Asia: the Peculiarities of their Spatial Temporal Structures, Zoning of Land and Waters. Vladivostok, 2019. P. 557-562. (In Russian)

17. Dangerous island. Natural risks of Sakhalin. Engineering Protection, No. 7 (March - April 2015), St. Petersburg, Russia, 2015. 24-38. (In Russian)

18. Oil-shipping terminal De-Kastri of the Sakhalin-1 Project, Sakhalin-info. Available online: https://sakhalin.info/ news/109770 (accessed on 12 November 2015). (In Russian)

19. The atlas of natural and technogenic hazards and emergency risks. M.: the Ministry of Emergency Measures of the Russian Federation, 2007. 324 p.

20. Tsunami hazard map of the Far Eastern coast of the Russian Federation for the 1,000 years interval of repeatability. [The Electronic resource]. https://nat-geo.ru/nature/sostavlena-karta-tsunami-opasnosti-v-regionakhrossii/ . (Date of the reference 28.09.2018). 